The Voluntary Food Intake of Pigs

Occasional Publication No. 13-British Society of Animal Production 1989

edited by J. M. Forbes, M. A. Varley and T. L. J. Lawrence

\title{
THE EFFECTS OF WATER DELIVERY RATE ON THE VOLUNTARY FOOD INTAKE, WATER USE AND PERFORMANCE OF EARLY-WEANED PIGS FROM 3 TO 6 WEEKS OF AGE
}

\author{
J. BARBER, P. H. BROOKS and J. L. CARPENTER \\ Seale-Hayne College, Newton Abbot, Devon TQ12 6NQ
}

\section{INTRODUCTION}

$\mathbf{I}^{\mathbf{t}}$ has been reported that the intake of water by pigs, like that of most mammals, is usually positively correlated with food intake. Water is commonly supplied to weaned piglets either from bowls or from drinkers. With the exception of water bowls with a large reservoir capacity, the availability of water to the pig depends upon the water delivery rate from the drinker. Despite this, few manufacturers of piglet drinkers recommend an optimum water delivery rate for their product. The objective of this experiment was to investigate the effect of different water delivery rates on the voluntary food and water intakes of young pigs.

\section{MATERIAL AND METHODS}

One hundred and sixty Large White $\times$ (Large White $\times$ Landrace) piglets aged $21 \pm 1$ days were randomly assigned to one of four water delivery rates $(700,450$, 350 and $175 \mathrm{~cm}^{3} / \mathrm{min}$ ) in four replicate blocks. The piglets were housed in an early-weaning flatdeck house maintained at $28^{\circ} \mathrm{C}$. Each treatment pen contained five boars and five gilts (weaning weight $5 \cdot 84$ (s.e.' $0 \cdot 3$ ) kg). The experimental design was a $4 \times 4$ Latin square, each of the four treatments occurring once in each of the four treatment pens. Water was supplied to each pen by two
Arato 76 drinkers and water used was metered through previously calibrated Kent PSM-L turbine meters and recorded daily. Water delivery rate was determined by the use of different restricted orifices in the drinkers. The delivery rates achieved were within $5 \%$ of the nominal values. For the first 2 weeks post weaning the piglets were fed ad libitum Bibby's D20M diet (oil $210 \mathrm{~g}$, protein $200 \mathrm{~g} / \mathrm{kg}$ ) and for the 3rd week Bibby's D10P diet (oil $100 \mathrm{~g}$, protein $240 \mathrm{~g} / \mathrm{kg}$ ). Food intake was calculated weekly.

\section{RESULTS AND DISCUSSION}

Piglet performance data are presented in Table 1. By making the attainment of water more difficult, voluntary food intake during the 3-week period immediately post weaning was significantly reduced $(P<0.001)$ and consequently average daily live-weight gain was significantly reduced $(P<0.01)$. There were no significant differences in voluntary food intake and daily gain between $700 \mathrm{~cm}^{3} / \mathrm{min}$ and $450 \mathrm{~cm}^{3} / \mathrm{min}$ water delivery rates.

Mean voluntary water use increased significantly at each water delivery rate $(P<0 \cdot 001)$. The apparent time spent drinking was calculated by dividing the mean water use by the delivery rate. This is not strictly the time spend drinking but the time the valve in the drinker was

TABLE 1

The effects of water delivery rate on voluntary food intake and water use

Water delivery rate $\left(\mathrm{cm}^{3} / \mathrm{min}\right)$

\begin{tabular}{|c|c|c|c|c|c|c|}
\hline & \multicolumn{4}{|c|}{ Water delivery rate $\left(\mathrm{cm}^{3} / \mathrm{min}\right)$} & \multirow[b]{2}{*}{ s.e.d. } & \multirow[b]{2}{*}{ Significance } \\
\hline & 175 & 350 & 450 & 700 & & \\
\hline Daily food intake (g per pig) & $303^{c}$ & $323^{b}$ & $341^{\mathrm{a}}$ & $347^{\mathrm{a}}$ & 3.68 & $* * *$ \\
\hline Daily gain (g per pig) & $210^{c}$ & $235^{\mathrm{b}}$ & $250^{4}$ & $247^{\mathrm{a}}$ & $5 \cdot 57$ & $* *$ \\
\hline Food conversion ratio & 1.48 & 1.39 & 1.37 & 1.42 & 0.03 & \\
\hline $\begin{array}{l}\text { Daily voluntary water use } \\
\text { (l per pig) }\end{array}$ & $0.78^{\mathrm{d}}$ & $1.04^{\mathrm{c}}$ & $1 \cdot 32^{\mathrm{b}}-(-\mathrm{c}-\mathrm{c}$ & $1 \cdot 63^{\mathrm{a}}$ & 0.01 & $* * *$ \\
\hline $\begin{array}{l}\text { Apparent time spent drinking } \\
\text { (s per pig per day) }\end{array}$ & $268 \cdot 1^{\mathrm{b}}$ & $175 \cdot 8^{\mathrm{a}}$ & $174 \cdot 8^{\mathrm{a}}$ & $139 \cdot 4^{\mathrm{a}}$ & $15 \cdot 44$ & $* * *$ \\
\hline
\end{tabular}


fully open. Time spent drinking at $175 \mathrm{~cm}^{3} / \mathrm{min}$ was significantly greater than at any of the other flow rates $(P<0.001)$. It is evident that the pigs had adapted to a certain extent to the lower flow rate by spending a greater amount of time drinking but this did not prevent a reduction in food intake. Nienaber and Hahn (1984) also found that there was no difference in apparent time spent drinking for early-weaned piglets between 350 and $1100 \mathrm{~cm}^{3} \mathrm{~min}$. Barber, Brooks and Carpenter (1988) showed that food intake in growing pigs was unaffected by water delivery rate of 300 or $900 \mathrm{~cm}^{3} / \mathrm{min}$ suggesting that growing pigs adapted to a greater extent to the lower water delivery rate.

Fitting second-order polynomial curves to the data gave the following equations:

$175 \mathrm{~cm}^{3} / \mathrm{min}: Y=0.379-0.014 X+0.0035 X^{2}$

$350 \mathrm{~cm}^{3} / \mathrm{min}: Y=0.655-0.043 X+0.0053 X^{2}$

$$
\left(R^{2}=0.98\right)
$$

$450 \mathrm{~cm}^{3} / \mathrm{min}: Y=0.773-0.033 X+0.0059 X^{2}$

$$
\left(R^{2}=0.98\right)
$$

$700 \mathrm{~cm}^{3} / \min : Y=0.681-0.008 X+0.0054 X^{2}$

$$
\left(R^{2}=0.98\right)
$$

where $Y=$ water use (l per pig per day)

$$
\left(R^{2}=0.98\right)
$$

$$
X=\text { days post weaning. }
$$

Although the relationship between water use and the number of days post weaning is highly significant, it does not adequately describe the pattern of water use during the first 2 days. Low water use on the 1 st day was followed by a rapid increase in intake on the 2 nd day suggesting that the piglets may have experienced difficulty in locating the drinkers immediately post weaning.
Linear regression in food intake on the water delivery rate gave the following equation:

$Y=293.1+0.084 X$

where $Y=$ food intake (g per pig per day)

$$
X=\text { delivery rate }\left(\mathrm{cm}^{3} / \mathrm{min}\right) \text {. }
$$

Linear regression of water delivery rate gave the following equation:

$Y=0.50+0.002 X$

where $Y=$ water intake (l per pig per day)

$X=$ delivery rate $\left(\mathrm{cm}^{3} / \mathrm{min}\right)$.

It is concluded that between the water delivery rates of $175 \mathrm{~cm}^{3} / \mathrm{min}$ and $450 \mathrm{~cm}^{3} / \mathrm{min}$ there is a significant increase in food intake. This highlights to the producer the importance of a readily available source of water during the period immediately post weaning. Many studies of the voluntary food intake in young pigs may have been biased by the water delivery system. Therefore it is recommended that future research concerning voluntary food intake in early-weaned pigs should be conducted using readily available water sources which do not themselves restrict voluntary food intake.

\section{REFERENCES}

Barber, J., Brooks, P. H. and Carpenter, J. L. 1988. The effect of water delivery rate and drinker number on the water use of growing pigs. Animal Production 46: 521 (Abstr.).

NiEnABER, J. A. and HAHN, G. L. 1984. Effect of water flow restriction and environmental factors on the performance of nursery-age pigs. Journal of Animal Science 59: 1423-1429. 